\title{
POPULATION KINETICS OF LOCALIZED STATES IN NANOCOMPOSITE MATERIALS UNDER EXPOSURE TO RADIATION
}

\author{
N.S. Dyuryagina, A.P. Yalovets \\ South Ural State University, Chelyabinsk, Russian Federation \\ E-mail: nsdiuriagina@susu.ru
}

We simulated the population of localized states in nanocomposite materials using Rouse-Fowler model. The following radiation effects were considered: prolonged irradiation (over $3 \mathrm{~s}$ ) with the low absorbed dose rate $(0,002 \mathrm{~W} / \mathrm{kg}$ ) and pulsed irradiation (100 ns) with the high absorbed dose rate (over $105 \mathrm{~W} / \mathrm{kg}$ ) of ionizing radiation. We investigated the role of localized states in electrical conductive properties of nanocomposite materials on the example of nanocomposite materials with hole conductivity (polymathimethacrilate (PMMA) + CdS) and electron conductivity $\left(\alpha-\mathrm{Al}_{2} \mathrm{O}_{3}+\mathrm{SrO}\right)$, as well as in pure PMMA and $\alpha-\mathrm{Al}_{2} \mathrm{O}_{3}$. Our results indicate that the small traps influence the speed of relaxation to the equilibrium radiation induced electrical conductivity, while the deep traps, the depth of which is much greater than $k T$, have an impact on the sensitivity to an absorbed dose of ionizing radiation. Moreover, pure PMMA and nanocomposite materials based on it are unsuitable for dosimetry due to a large share of the small traps in the spectrum of intrinsic localized states. On the contrary, aluminum oxide is an almost perfect material for the accumulation of the information about the ionizing radiation, since its spectrum of localized states includes only deep traps. On the whole, the most interesting materials from the dosimetry viewpoint are nanocomposites based on aluminum oxide, where the concentration of impurity centers does not exceed the concentration of intrinsic states, and the nanoparticle radius is no more than $2 \mathbf{n m}$ in case of small share of the small traps in impurity spectrum.

Keywords: nanocomposite material; localized state; localized center; trap; radiation induced electrical conductivity; Rouse-Fowler; dosimetry; polymathilmethacrilte (PMMA); $\mathrm{CdS} ; \alpha-\mathrm{Al}_{2} \mathrm{O}_{3}$; corundum; $\mathrm{SrO}$.

\section{Introduction}

Electrophysical properties of dielectrics and semiconductors are determined by charge carriers kinetics, which depends on the spectrum of localized states stipulated by different structural defects (intrinsic traps). For example, polymethilmethacrilate (PMMA) has an exponential spectrum of localized states for holes [1-2], while the spectrum of localized centers of $\alpha-\mathrm{Al}_{2} \mathrm{O}_{3}$ includes only deep traps for electrons, that makes possible the usage of this material in dosimetry [3-7].

The introduction of nanoparticles into dielectric matrix material leads to an appearance of additional localized states, which stem from the formation of the potential well due to a difference in Fermi levels of materials at the nanoparticle-matrix interface (impurity traps). In contrast to intrinsic localized traps in the matrix, the concentration and energy spectrum of impurity traps can be changed by varying the concentration and size of nanoparticles. As a result, the nanocomposite materials with new properties can be created.

Based on PMMA+CdS nanocomposite material different photogalvanic and optoelectronic devices are created [8]. Since high-radiation conditions should not affect the instrumental data of these devices, the question arises about radiation resistance of PMMA+CdS. On the other hand, corundum $\left(\alpha-\mathrm{Al}_{2} \mathrm{O}_{3}\right)$ and nanocomposite materials on its basis are sensitive to radiation and able to register and save information about absorption dose for a long time, until the sample is exposed to external effects, for example, by heating.

To investigate phenomena mentioned above it is necessary to study the electrophysical properties of nanocomposite materials under radiation effect.

Rouse-Fowler equation system describes the kinetics of charge carriers in the band gap and allows us to describe different electrophysical properties of a dielectric material. In the frame of Rouse-Fouler 
model, the radiation electrical conductivity of polymer materials $[3,9-11]$ and the dose dependence of termostimulated luminescence of the pure $\alpha-\mathrm{Al}_{2} \mathrm{O}_{3}$ under radiation effect with low dose rates [4-7] were investigated. The existing solutions of Rouse-Fowler equation system consider only pure materials, where energy spectrum of traps has one or two energy levels [4-7], or the case, where trap energy distribution follows the exponential law [3, 9-11]. To describe the electrophysical properties of nanocomposite materials we need to solve Rous-Fowler equation system for a random spectrum of localized states.

This work aims to investigate physical processes, which determine the kinetics of charge carrier in the pure PMMA and $\alpha-\mathrm{Al}_{2} \mathrm{O}_{3}$, as well as in nanocomposite materials made of them, under gamma-rays exposure with low and big dose rates. By knowing these physical processes we could evaluate the possibility of application of these materials in dosimetry. Since electrophysical properties of nanocomposite materials are determined by intrinsic and impurity localized states, here we studied the population of localized states.

\section{Mathematical model}

Properties of polymer materials are well understood. In polymer the distribution of intrinsic localized states, which stem from defects of the matrix materials, follows the exponential law [3]:

$$
N(E)=N_{0} / k T_{1} \exp \left(-E / k T_{1}\right),
$$

where $N_{0}$ is the full concentration of intrinsic traps, $T_{1}$ is the distribution parameter.

To calculate the energy spectrum of localized states originated from the spherical nanoparticle introduction into the matrix material, we solved the Schrodinger equation with the following potential [12]:

$$
U(r)=\left\{\begin{array}{c}
-U_{0}, \quad r \leq R_{p a t} ; \\
-U_{0} R_{p a t} \cdot \exp \left(-\left(r-R_{p a t}\right) / r_{D}\right) / r, \quad r>R_{p a t},
\end{array}\right.
$$

where $R_{p a t}$ is the nanoparticle radius, $U_{0}=\left|W_{m}-W_{p a t}\right|$ is the deep of the potential, $W_{m}$ and $W_{p a t}$ are work functions for the matrix and the nanoparticle, respectively, $r_{D}$ - the shielding length, which determines the width of the potential well. The radius $r_{D}$ is determined so that the number of states in the potential well was not less than $q_{p a t} / 2 e$, where $q_{p a t}=C_{p a t} \cdot U_{0}$ is the nanoparticle charge, $C_{p a t}$ is the nanoparticle capacitance [12].

Rouse-Fowler equation system, which describes the kinetics of free and localized on traps carrier, has the form:

$$
\begin{gathered}
\dot{n}=S-\alpha n\left[p+\sum_{l=1}^{l_{0}} p_{l}\right]-n \sum_{m=1}^{m_{0}} K_{m}+\sum_{m=1}^{m_{0}} \frac{n_{m}}{\tau_{m}}+S_{p a t} ; \\
\dot{p}=S-\alpha p\left[n+\sum_{m=1}^{m_{0}} n_{m}\right]-p \sum_{l=1}^{l_{0}} K_{l}+\sum_{l=1}^{l_{0}} \frac{p_{l}}{\tau_{l}} ; \\
\dot{n}_{m}=K_{m} n-\frac{n_{m}}{\tau_{m}}-\alpha p n_{m}-S_{p a t}^{\prime} \delta_{m, m_{0}}, \quad 1 \leq m \leq m_{0} ; \\
\dot{p}_{l}=K_{l} p-\frac{p_{l}}{\tau_{l}}-\alpha n p_{l}+\left(S_{p a t}-S_{p a t}^{\prime}\right) \delta_{l, \tilde{l}_{0}+1}, \quad 1 \leq l \leq l_{0},
\end{gathered}
$$

where $n, p$ are the concentrations of free electrons and holes; $n_{m}$ and $p_{l}$ are the concentrations of trapped electrons and holes; $m_{0}$ and $l_{0}$ are the numbers of energy levels for electrons and holes; $1 \leq m \leq \tilde{m}_{0}$ and $1 \leq l \leq \tilde{l}_{0}$ are indexes for intrinsic traps; $\left(\tilde{m}_{0}+1\right) \leq m \leq m_{0}$ and $\left(\tilde{l}_{0}+1\right) \leq l \leq l_{0}$ are indexes for impurity traps; $\alpha$ is the recombination coefficient; $\tau_{m, l}=v_{m, l}^{-1} \exp \left(E_{m, l} / k T\right)$ are life times of charge carriers on electron and hole traps, $v_{m, l}$ are frequency factors. $K_{m}=k_{m}\left(M_{m}-n_{m}\right)$ and $K_{l}=k_{l}\left(L_{l}-p_{l}\right)$, where $k_{m, l}$ are capture coefficients, $M_{m}$ and $L_{l}$ are the concentrations of electron and 


\section{Физика}

hole traps, respectively. $S$ and $S_{p a t}$ are the volumetric generation rates of free charge carriers due to the ionization of the matrix material and the nanoparticle, respectively. For donor inclusion the generation rate is $S_{p a t}^{\prime}=S_{p a t}$, for acceptor one $S_{p a t}^{\prime}=0$.

The last summands in (3) and (4) take into account the fact that under ionization of the donor inclusion the electron localized on the deepest trap becomes free, while the ionization of the acceptor inclusion leads to the hole localization on the top level [12].

The general idea of the system (1)-(4) solving is finding the approximate analytical solution for a certain time interval $\Delta t=t_{k+1}-t_{k}$, which we choose to minimize the bias of the found analytical solution.

The generation rates of charge carrier pairs in the matrix materials and the inclusion are determined by formulas:

$$
S=\left(1-f_{\text {pat }}\right) \rho D / w_{i}, \quad S_{\text {pat }}=f_{\text {pat }} \cdot\left(\rho D / w_{i}\right)_{\text {pat }},
$$

where $\rho$ is the mass density of matter, $D$ is the radiation energy absorbed by unit mass of substance per unit time, $w_{i}$ is the average energy of free charge carrier pair generation, $f_{p a t}$ is the volume ration of nanoparticles in nanocomposite materials, the values in brackets with the pat index are determined for nanoparticles.

Previously, we showed that the ionization of inclusion has the contribution to the ionization of nanocomposite materials, comparable with the ionization of matrix material [12].

The capture coefficient of free charge carrier on the level with energy $E$ is determined by the formula $k_{E}=v \sigma_{a}(E)$, where $v$ is the speed of free charge carrier (Fermi speed), $\sigma_{a}(E)=\pi r_{E}^{2} K_{a}$ - the capture cross-section. Here $r_{E}$ is the radius of localized states with the energy $E$, which is determined from the condition $U\left(r_{E}\right)=E, K_{a}$ is the probability of the charge capture.

The frequency factor characterizes the release of trapped charge carriers from level with energy $E$. It determined by the formula $v_{E}=h /\left(4 r_{E}^{2} m_{*}\right)$, where $h$ is Planck constant, $m_{*}$ - the effective mass of the charge carrier.

The parameters $K_{a}$ and $m_{*}$ are evaluated from the estimation that the physical nature of the capture on intrinsic and impurity centers is the same. Since the radius of the intrinsic center, determined by structure defects, has the order of $1 \mathrm{~nm}$, the values of the capture coefficient and the frequency factor for the small size impurity center $(1 \mathrm{~nm})$ will be comparable to the values for the intrinsic traps. As a result, the following constants were obtained: for the acceptor inclusion are $K_{a} \sim 10^{-6}, m_{*} \sim 10^{-2}-10^{-9} m_{e}$, ( $m_{e}$ - the electron mass), for the donor inclusion are $K_{a} \sim 10^{-9}-10^{-14}, m_{*} \sim m_{e}$.

Given that the impurity spectrum of localized states belongs to one nanoparticle, it is highly probable that charge carriers trapped on the impurity localized state will be trapped on the deeper level, as they tend to the minimum energy. Thus, considering the excitation of charge carrier within the potential well, the concentration of the charge carrier $n_{m}\left(p_{\nu}\right)$ localized on the impurity trap with energy $E_{m}\left(E_{\nu}\right)$ follows Boltzmann distribution.

We tested the method for calculation of the charge carrier kinetics on the case of two traps and on the case of the exponential distribution of the localized states. We showed [12], that the values of radiation induced electrical conductivity calculated by this method are in the good agreement with results obtained by other authors.

It is important to note, that we consider only low values of absorbed energy (below $10^{3} \mathrm{~J} / \mathrm{kg}$ ), so the heating does not exceed a few Kelvin degrees. It allows us to neglect the temperature effects. Radiation damages are not considered, so the concentration of localized centers is constant.

\section{Results and discussions}

For further analysis of the role of localized states in the formation of conductive properties of the nanocomposite materials, it is convenient to mark the deep traps with the energy $\left|E_{n}\right| \gg k T$. The deep traps are characterized by a lifetime sufficient for charge retention without external action. 
PMMA possess a hole conductivity and its intrinsic trap spectrum follows the exponential law with the distribution parameter $T_{1}=2150 \mathrm{~K}$ and the full concentration $N_{0}=10^{25} \mathrm{~m}^{-3}$ [13]. By discretization of the continuum spectrum of the intrinsic localized states, we obtained 16 energy levels with the energy range from 0,05 to $0,93 \mathrm{eV}$. Other parameters for calculation of the charge carrier kinetics in PMMA are $\alpha=10^{-14} \mathrm{~m}^{3} / \mathrm{s}, k_{E}=10^{-16} \mathrm{~m}^{3} / \mathrm{s}, v_{E} \sim 10^{4} \mathrm{~s}[3]$.

The introduction of the CdS nanoparticles into PMMA leads to the formation of the hole potential well with the deep of $1,37 \mathrm{eV}$. For nanoparticle with radius $2 \mathrm{~nm}$ the 3 energy levels $\left(E_{m}=0,52 ; 0,99\right.$;

$1,27 \mathrm{eV}$ ) are formed, which are deep at the room temperature. Increase in size of nanoparticles leads to increase in a number of energy levels in the bandgap and to the appearance of the small traps. For CdS nanoparticle with radius $5 \mathrm{~nm}, 9$ energy levels are formed with 2 traps, which are small at $300 \mathrm{~K}$. For nanoparticle with radius $10 \mathrm{~nm}-5$ of 19 traps are small.

The kinetics of charge carriers in the PMMA+CdS nanocomposite materials was simulated in two stages. On the first stage, the established electrical conductivity of the unirradiated nanocomposite materials was calculated with the following initial conditions: all intrinsic traps are empty, all impurity traps are filled. The populations of localized traps obtained on the first stage were used as the initial condition for the kinetics calculation of the charge carriers under radiation effect on the second stage.

Figure 1 shows that after irradiation the electrical conductivity tends to the value, that remains constant $\left(R_{\text {pat }}=2 \mathrm{~nm}\right)$ or slowly changes $\left(R_{\text {pat }}=5 \mathrm{~nm}\right)$. We will call this value the equilibrium value due to the equilibrium between processes of the charge carrier recombination, the charge carrier capture on traps and the charge carrier release from them. For the pure PMMA and for the nanocomposite material, when the radius inclusion is $R_{\mathrm{pat}}=10 \mathrm{~nm}$, the equilibrium is reached much later, than it is shown on Fig. $1\left(\sim 10^{6} \mathrm{~s}\right)$. The equilibrium value of the radiation-induced electrical conductivity depends on the size and the concentration of the nanoparticles due to the appearance of additional charge carriers, which release from the impurity centers [12].

As the calculations of radiation-induced electrical conductivity for pure PMMA were carried out for the initial condition (all intrinsic traps are empty), we can see the dependence of the intrinsic trap population on the absorbed dose rate (Fig. 2). The existence of deep traps in the spectrum of PMMA makes this material sensitive to radiation, but the high concentration of small traps increases the relaxation time to $\sim 10^{6} \mathrm{~s}$, so pure PMMA is unsuitable for dosimetry (Fig. 1).

In the case when the impurity center concentration exceeds the concentration of the intrinsic centers the introduction of the CdS nanoparticles with the radius from 2 to $10 \mathrm{~nm}$ leads to full occupancy of deep intrinsic traps by charge carriers released from the small impurity traps. This nanocomposite can-

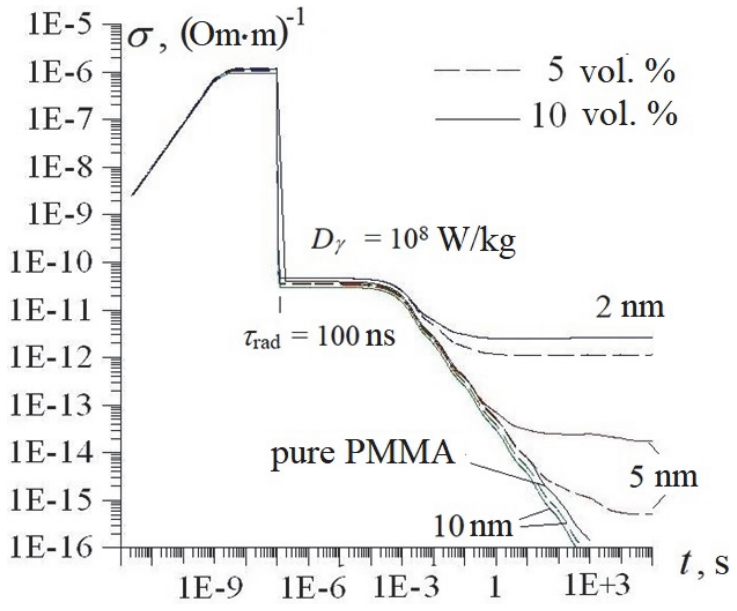

Fig. 1. Dependence of radiation induced electrical conductivity of the pure PMMA and the PMMA with inclusion of CdS nanoparticle on radius $R_{\text {pat }}$.

Pulsed irradiation $\left(10^{8} \mathrm{~W} / \mathrm{kg}, 100 \mathrm{~ns}\right)$; at $T=300 \mathrm{~K}$

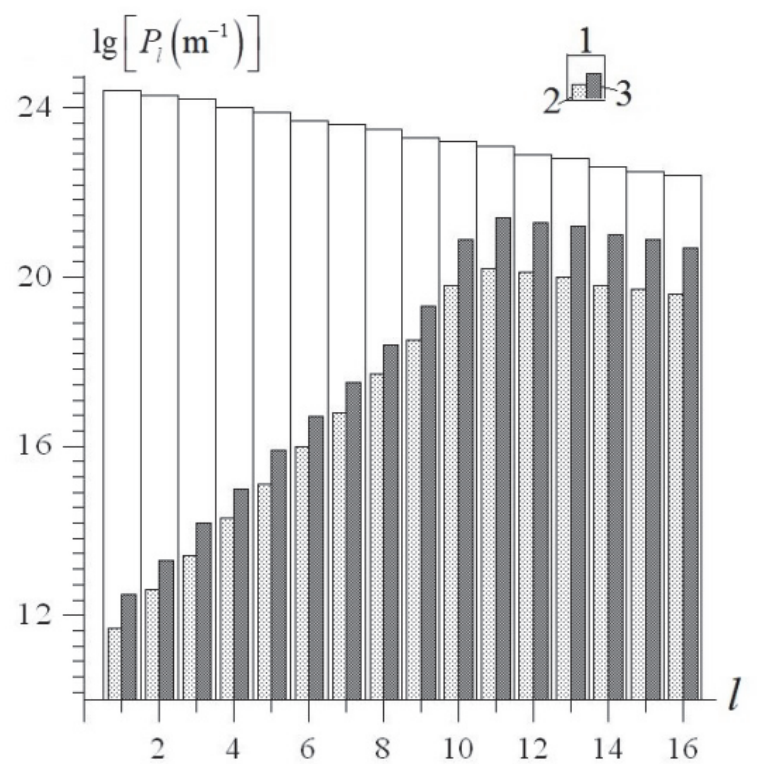

Fig. 2. Dependence of equilibrium population of intrinsic traps for pure PMMA after irradiation on the absorption dose rate: 1 - concentration of localized states; 2, 3 - concentration of trapped charge carriers: 2 - at the absorption dose rate of $10^{8} \mathrm{~W} / \mathrm{kg}$; $3-10^{10} \mathrm{~W} / \mathrm{kg}$ 


\section{Физика}

not save the information about the absorbed energy because the charge carrier appeared by irradiation are localized by the insufficiently deep for this process traps.

Aluminum oxide has the electron conductivity and its energy spectrum of the intrinsic localized states includes only two deep energy levels with energies $E_{1}=1,3 \mathrm{eV}$ and $E_{2}=1,6 \mathrm{eV}$, and concentrations $M_{1}=10^{21} \mathrm{~m}^{-3}$ и $M_{2}=10^{20} \mathrm{~m}^{-3}$, respectively [4-7]. The absence of small traps in the spectrum of localized states makes this material almost perfect for usage in dosimetry. This material has the short relaxation time (less than $10 \mathrm{~s}$ ) and the ability to cumulate and save information about the absorbed energy. Since the capture coefficient on the trap with the energy $E_{2}\left(k_{2} \sim 10^{-25} \mathrm{~m}^{3} / \mathrm{s}\right)$ is small, all information about the absorbed energy by the pure aluminum oxide is saved by the trap with the energy $E_{1}\left(k_{1} \sim 10^{-20}\right.$ $\mathrm{m}^{3} / \mathrm{s}$ ). Since $\alpha-\mathrm{Al}_{2} \mathrm{O}_{3}$ is able to trap charge carriers for a long time (up to $10^{8} \mathrm{~s}$ ), it is necessary to anneal it to empty the traps before irradiation. Other parameters for calculation of the charge carriers kinetic in $\alpha-\mathrm{Al}_{2} \mathrm{O}_{3}$ are: $\alpha \sim 10^{-19} \mathrm{~m}^{3} / \mathrm{s}, v_{E} \sim 10^{13} \mathrm{~s}^{-1}[4]$.

Figure $3 a$ shows the population of the energy level $E_{1}$ depending on the absorbed energy at the $T=300 \mathrm{~K}$ and the different absorbed dose rates by lines $1(0,002 \mathrm{~W} / \mathrm{kg}$ ) and 2 (pulsed irradiation with duration $100 \mathrm{~nm}$ and at the absorbed dose rate from $10^{5} \mathrm{~W} / \mathrm{kg}$ ).

In the case of prolonged irradiation (from $3 \mathrm{~s}$ ) and small absorbed dose rate $0,002 \mathrm{~W} / \mathrm{kg}$ (line 1, Fig. $3 a$ ) the trap with the energy $E_{1}$ is filled almost completely and the absorbed energy $\sim 100 \mathrm{~J} / \mathrm{kg}$. In the case of pulsed irradiation (100 ns) and absorbed dose rate from $10^{5} \mathrm{~W} / \mathrm{kg}$ (line 2, fig. 3a) the population of the trap does not exceed $20 \%$ even at $10^{5} \mathrm{~J} / \mathrm{kg}$. This difference stems from the fact, that at the high absorbed dose rate the main process during system relaxation is the recombination of the charge carriers, but at the low absorbed dose rate - the capture of the charge carriers by traps.

The lowering of temperature does not influence the localized state population of the pure aluminum oxide.

The introduction of the $\mathrm{SrO}$ nanoparticles to aluminum oxide leads to the formation of the electron potential well with the deep of $1,05 \mathrm{eV}$. For the nanoparticles radius of $2 \mathrm{~nm}, 6$ energy levels with the deeps from 0,01 to $0,84 \mathrm{eV}$ are formed in the potential well. At a room temperature only one level is deep. Increase in the nanoparticle radius to $10 \mathrm{~nm}$ leads to increase in a number of energy levels up to 32 , and 25 of them are small.

To determine the initial condition of the nanocomposite material (NM) the NM was annealed. The annealing simulation of the NM consisted of two stages. The first stage is heating of the NM up to $600 \mathrm{~K}$ (with the heating speed $2 \mathrm{~K} / \mathrm{s}$ for 1 hour) from the following initial condition: all intrinsic traps are empty, all impurity traps are filled. The second stage is cooling and relaxation of the NM to the equilibrium state at the temperature, at which the NM was further irradiated. The population of the localized states obtained on the second stage will be used as the initial condition to simulate the kinetics of the charge carrier in the NM under radiation effect.

The introduction of 1 vol. \% (and more) of SrO nanoparticles with radius below $10 \mathrm{~nm}$ leads to the appearance of the impurity centers, which concentration exceeds the concentration of the intrinsic centers. After annealing all intrinsic localized states are completely filled and the resulting conductive properties are determined only by impurity centers. The spectrum of the impurity localized states includes the small traps, which are emptied due to their thermal activation, so the dark conductivity of this NM is much greater than that of pure aluminum oxide and constitutes $\sim 1-100(\mathrm{Om} \cdot \mathrm{m})^{-1}$. The deep traps that should save information of the absorbed energy are always filled in this NM.

The most interesting case is the NM in which the concentration of the impurity centers does not exceed the concentration of the intrinsic centers, and the spectrum of the impurity states does not include small traps. For example, the concentration of the $\mathrm{SrO}$ nanoparticles (with the radius of $2 \mathrm{~nm}$ ) of $5 \cdot 10^{-5}$ vol. \% corresponds to the concentration of the impurity states of $1,45 \cdot 10^{19} \mathrm{~m}^{-3}$, which is comparable to the concentration of the deepest intrinsic trap $\left(\sim 10^{20} \mathrm{~m}^{-3}\right)$.

In Table 1 we present the initial conditions for the calculation of the kinetics of the charge carrier in the $\alpha-\mathrm{Al}_{2} \mathrm{O}_{3}+\mathrm{SrO}$ at the temperature 100 and $300 \mathrm{~K}$, obtained after annealing.

In the heating process all impurity traps with deep $E_{m} \leq E_{7}$ are almost completely exempted due to the small lifetimes, filling the intrinsic localized states $E_{1}$ и $E_{2}$. Because levels with $E_{2}$ are completely filled, the intrinsic trap with energy $E_{1}$ will play the main role in the storage of charge carriers after irradiation. The impurity energy levels with energies $E_{7}$ и $E_{8}$ are deep at the temperature $100 \mathrm{~K}$. 
The equilibrium populations of the localized stats for the $\mathrm{Al}_{2} \mathrm{O}_{3}+\mathrm{SrO}$ nanocomposite

(nanoparticle radius is $2 \mathrm{~nm}$ and concentration is $5 \cdot 10^{-5}$ vol. \%) after the annealing

\begin{tabular}{|c|c|c|c|c|c|}
\hline \multirow{2}{*}{$m$} & \multirow{2}{*}{$\begin{array}{c}\text { Energy } \\
E_{m}, \mathrm{eV}\end{array}$} & $\begin{array}{c}\text { Population } \\
\frac{n_{m}}{M_{m}} \cdot 100, \%\end{array}$ & $\begin{array}{c}\text { Lifetime } \\
\tau_{\mathrm{m}}, \mathrm{c}\end{array}$ & $\begin{array}{c}\text { Population } \\
\frac{n_{m}}{M_{m}} \cdot 100, \%\end{array}$ & $\begin{array}{c}\text { lifetime } \\
\tau_{\mathrm{m}}, \mathrm{c}\end{array}$ \\
\hline \multicolumn{7}{|c|}{ Intrinsic traps } \\
\hline 1 & 1,3 & 5,9 & $\rightarrow \infty$ & 7,91 & $\sim 10^{8}$ \\
\hline 2 & 1,6 & $\sim 100$ & $\rightarrow \infty$ & $\sim 100$ & $\sim 10^{13}$ \\
\hline \multicolumn{7}{|c|}{ Impurity traps } \\
\hline $3-7$ & $0,01-0,56$ & $\sim 0$ & $\sim 10^{-12}-10^{15}$ & $\sim 0$ & $\sim 10^{-12}-10^{-4}$ \\
\hline 8 & 0,84 & 67,4 & $\rightarrow \infty$ & $\sim 0$ & 20,6 \\
\hline
\end{tabular}

After irradiation the NM captures charge carriers firstly on the intrinsic trap $E_{1}$. The dependence of its established population on the absorbed energy and temperature in comparison with the pure aluminum oxide is presented in Fig. $3 a$. In the case of prolonged irradiation (from $3 \mathrm{~s}$ ) and the low absorbed dose rate $0,002 \mathrm{~W} / \mathrm{kg}$ (lines $1,3,5$ in Fig. $3 a$ ) the trap is filled almost completely at the absorbed energy of $20 \mathrm{~J} / \mathrm{kg}$. In the case of pulsed irradiation $\left(100 \mathrm{~ns}\right.$ ) with the absorbed dose rate from $10^{5} \mathrm{~W} / \mathrm{kg}$ (lines 2 , 4, 6 in Fig. $3 a$ ), the population of the trap does not exceed $30 \%$ even at the absorbed energy of $10^{5} \mathrm{~J} / \mathrm{kg}$. As we mentioned above, at the high absorbed dose rate the main process of the equilibrium establishment is the recombination of the charge carriers, but at the low absorbed dose rate - the capture by traps.

Unlike the pure aluminum oxide, the initial population of the localized states are nonzero, so the established population of the localized states of the nanocomposite materials after irradiation is higher (lines 3-6, Fig. 3a) than in the pure aluminum oxide (lines 1-2, Fig. 3a).
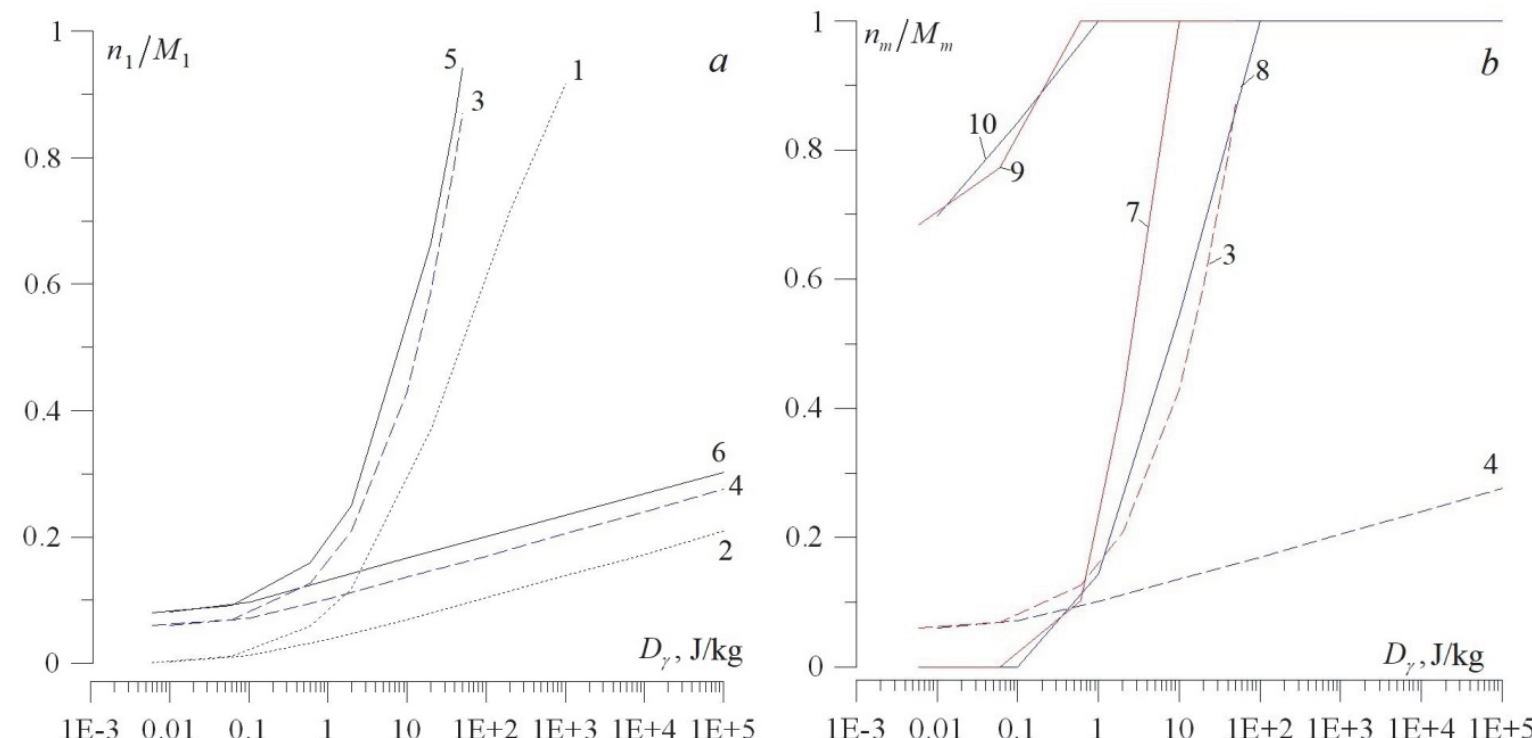

Fig. 3. Established population of intrinsic states with energy of $E_{1}(a)$ and impurity states with $E_{7}, E_{8}(b)$ after irradiation depending on absorbed energy: (a) - lines 1,2 are the pure $\mathrm{Al}_{2} \mathrm{O}_{3} ; 3,4$ are the $\mathrm{NM}$ at $100 \mathrm{~K} ; 5,6$ are the NM at $300 \mathrm{~K} ;(b)$ - population of localized states in the NM at $100 \mathrm{~K}$ : lines $3,4-E_{1} ; 7,8-E_{7}$ and $9,10-E_{8}$

The established population of the localized state $E_{1}$ in the nanocomposite material after irradiation at $T=100 \mathrm{~K}$ (lines 3 and 4, Fig. 3) is less than at $300 \mathrm{~K}$ (lines 5 and 6, Fig. 3a), because at low temperature part of charge carriers is retained by the deep impurity traps (lines 7-10, Fig. 3b). The impurity localized states with $E_{m} \leq E_{6}$ (table) are not deep enough to trap charge carriers even at the $100 \mathrm{~K}$. But with the absorbed energy $\sim 5 \mathrm{~J} / \mathrm{kg}$ in the case of prolonged irradiation (from $3 \mathrm{~s}$ ) and the low absorbed dose rate $0,002 \mathrm{~W} / \mathrm{kg}$ (lines 3, 7, 9, Fig. $3 b$ ) and $\sim 100 \mathrm{~J} / \mathrm{kg}$ in the case of the pulsed irradiation (100 ns) with the absorbed dose rate from $10^{5} \mathrm{~W} / \mathrm{kg}$ (lines $4,8,10$, Fig. $3 b$ ) the impurity traps with energies $E_{7}$ and $E_{8}$ 


\section{Физика}

are completely filled, so at the greater absorbed energy the main center of capture is the intrinsic trap with the energy $E_{1}$.

The population of the level with energy $E_{1}$ in the nanocomposite materials at the low absorbed dose rate (lines 3 and 5, Fig. $3 a$ ) increases faster with the rise of the absorbed energy than in pure aluminum oxide (lines 1 , Fig. $3 a$ ), which indicates the increase of material sensitivity to the absorbed energy (we define sensitivity as $\left.d n_{1} / d D_{\gamma}\right)$.

Figure 4 shows the time dependence of populations on levels with energies $E_{1}, E_{7}, E_{8}$ in the NM after irradiation at the temperature of $100 \mathrm{~K}$. The charge accumulation is more effective at the low absorbed dose rates because in this case the basic process in the establishment of equilibrium is the capture of charge carrier by traps.

The relaxation time is determined by the fraction of small traps. For nanocomposite materials at $300 \mathrm{~K}$ the relaxation time is $\sim 100 \mathrm{~s}$, which is 3 orders of magnitude more, than for pure aluminum oxide. With temperature decrease the fraction of small traps in the nanocomposite reduces. And at $100 \mathrm{~K}$

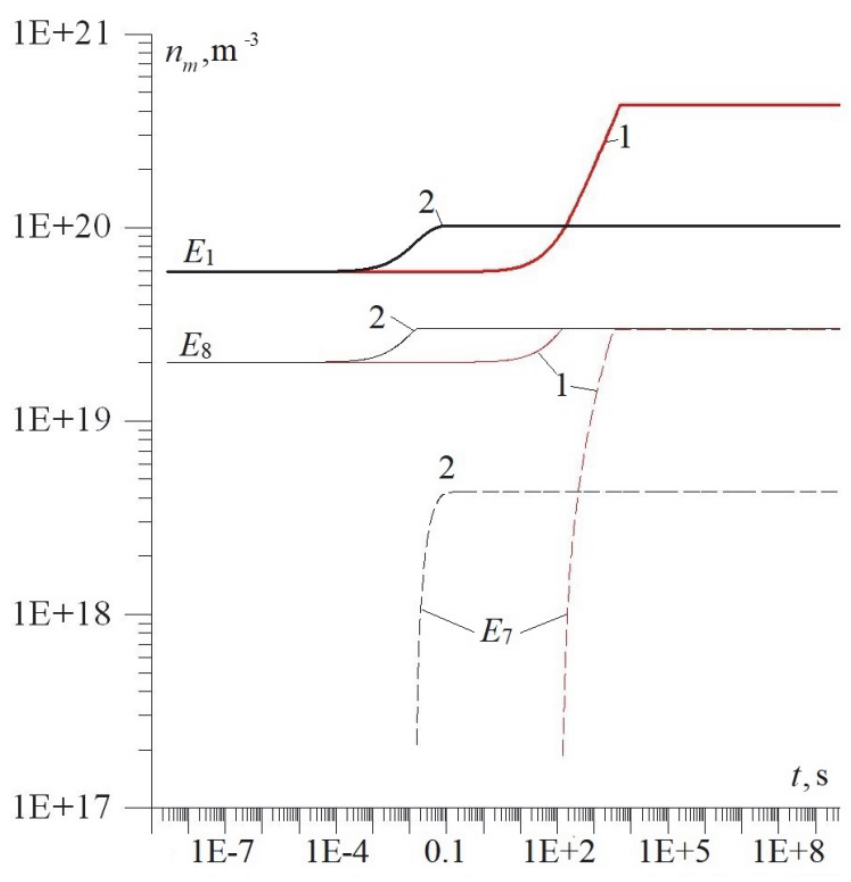

Fig. 4. Kinetics of localized charge carrier in $\mathrm{Al}_{2} \mathrm{O}_{3}+\mathrm{SrO}$ $\left(2 \mathrm{~nm}, 5.10^{-5} \mathrm{vol} . \%\right)$ under irradiation with absorbed energy of $10 \mathrm{~J} / \mathrm{kg}$ : 1 - prolonged irradiation $\left(0.002 \mathrm{~W} / \mathrm{kg}, 5.10^{-3} \mathrm{~s}\right) ; 2$ pulsed irradiation $\left(10^{8} \mathrm{~W} / \mathrm{kg}, 100 \mathrm{~ns}\right)$; at $T=100 \mathrm{~K}$ the relaxation time is $\sim 0,1 \mathrm{~s}$, which is comparable to pure aluminum oxide. The charge retention time of the nanocomposite materials at $300 \mathrm{~K}$ is negligibly lower than of pure aluminum oxide $\left(\sim 10^{8} \mathrm{~s}\right)$.

\section{Conclusion}

Localized states play the main role in the formation of electrical conductive properties of both pure and nanocomposite materials. The nanocomposites are promising materials because the possibility of controlling the energy spectrum of impurity localized states, which originates from the nanoparticle inclusion.

The large relaxation time to equilibrium state makes PMMA unsuitable for dosimetry. PMMA+CdS nanocomposite material returns to the equilibrium state fast, but this NM is not able to accumulate the information about the absorbed radiation energy.

From the dosimetry point of view, $\alpha-\mathrm{Al}_{2} \mathrm{O}_{3}$ has the ideal energy spectrum of intrinsic localized states. The introduction of SrO nanoparticles with concentration from 1 vol. \% leads to deep traps filling, making this material incapable to accumulate information about absorbed energy.

In case of the introduction of SrO nanoparticles with concentration of less than 1 vol. \%, the basic role in the accumulation of charge carriers is played by the intrinsic trap with the energy of $1,3 \mathrm{eV}$ (this trap is partially filled after annealing). After irradiation even with the absorbed energy of $20 \mathrm{~J} / \mathrm{kg}$ (prolonged irradiation with the low absorbed dose rate) the trap is almost completely filled, which makes it difficult to accumulate charge carriers in case of longer irradiation. In the case of pulsed irradiation, when the basic process of relaxation to equilibrium state is the charge carrier recombination, the population of the intrinsic trap with the energy of $1,3 \mathrm{eV}$ does not exceed $30 \%$ even with the absorbed dose rate $10^{5} \mathrm{~J} / \mathrm{kg}$.

Summing up, the creation of the nanocomposite materials should meet the following requirement: the concentration of the impurity localized states, which stems from the nanoparticle introduction, should not exceed the concentration of the intrinsic localized states of the matrix material. Otherwise, the intrinsic deep traps will be completely filled and will not be able to accumulate and save the information about the absorbed radiation energy. The nanoparticle dimensions should not exceed $\sim 2-5 \mathrm{~nm}$. The large size of nanoparticles leads to the formation of the large proportion of small traps in the energy 
spectrum of impurity localized stated, that makes the relaxation time long, so the material will not be sensitive to the absorbed radiation energy.

This study was supported in part by the Ministry of Education and Science of the Russian Federation (research work of South Ural State University (Research University)) under state assignment no. 3.9684.2017/BP (no. 2017122-GZ)

\section{References}

1. Popov V.K., Bagratashvili V.N., Krotova L.I., Rybaltovskii A.O., Smith D.C., Timashev P.S., Yang J., Zavorotnyi Yu.S., Howdle S.M. A route to diffusion embedding of CdSe/CdS quantum dots in fluoropolymer microparticles. Green Chemistry, 2011, Vol. 13, no. 10, pp. 2696-2700. DOI: $10.1039 / \mathrm{C} 1 \mathrm{GC} 15553 \mathrm{~A}$

2. Tomczak N., Janczewski D., Han M., Vancso G.J. Designer polymer-quantum dot architectures. Progress in Polymer Science, 2009, Vol. 34, Issue 5, pp. 393-430. DOI: $10.1016 /$ j.progpolymsci.2008.11.004

3. Vannikov A.V., Matveev V.K., Sichkar' V.K., Tyutnev A.P. Radiatsionnye effekty v polimerakh. Elektricheskie svoystva (Radiation effects in polymers. Electrical properties). Moscow, Nauka Publ., 1982, 273 p. (in Russ.).

4. Kortov V.S., Milman I.I., Nikiforov S.V. Bulletin of the Tomsk Polytechnic University, 2000, Vol. 303, pp. 35-45. (in Russ.).

5. Milman I.I., Kortov V.S., Kirpa V.I. Physics of the Solid State, 1995, Vol. 37, Issue 4, pp. 1149 1159. (in Russ.).

6. Nikiforov S.V., Kortov V.S., Kazantseva M.G. Simulation of the superlinearity of dose characteristics of thermoluminescence of anion-defective aluminum oxide. Physics of the Solid State, 2014, Vol. 56, Issue 3, pp. 554-560. DOI: 10.1134/S1063783414030214

7. Nikiforov S.V., Kortov V.S. Simulation of sublinear dose dependence of thermoluminescence with the inclusion of the competitive interaction of trapping centers. Physics of the Solid State, 2014, Vol. 56, Issue 10, pp. 2064-2068. DOI: 10.1134/S1063783414100229

8. Shamilov R.R., Galyametdinov Yu.G. Bulletin of the Technological University, 2013, Vol. 16, Issue 15, pp. 322-324. (in Russ.).

9. Tyutnev A.P., Vannikov A.V., Mingaleev G.S. Radiatsionnaya elektrofizika organicheskikh dielektrikov (Radiation electrophysics of organic dielectrics). Moscow, Energoatomizdat Publ., 1989, 192 p. (in Russ.).

10. Tyutnev A.P., Sadovnichii D.N., Boev S.G. High Energy Chemistry, 1995, Vol. 29, pp. 115119. (in Russ.).

11. Tyutnev A.P., Saenko V.S., Pozhidaev E.D., Ikhsanov R. Experimental and Theoretical Studies of Radiation-Induced Conductivity in Spacecraft Polymers. IEEE transactions on plasma science, 2015, Vol. 43, Issue 9, pp. 2915-2924. DOI: 10.1109/TPS.2015.2403955

12. Dyuryagina N.S., Yalovets A.P. Using Rouse-Fowler model to describe radiation-induced electrical conductivity of nanocomposite materials. J. Phys.: Conf. Ser., 2017, Vol. 830, Issue 1, pp. 1213012136. DOI: $10.1088 / 1742-6596 / 830 / 1 / 012130$

13. Vaysberg S.E., Sichkar' V.P., Karpov V.L. Vysokomolekulyarnye soedineniya, 1971, Vol. (A)13, no. 11, pp. 2502-2507. (in Russ.). 


\title{
КИНЕТИКА НАСЕЛЕННОСТИ ЛОКАЛИЗОВАННЫХ СОСТОЯНИЙ НАНОКОМПОЗИЦИОННЫХ МАТЕРИАЛОВ ПРИ РАДИАЦИОННОМ ВОЗДЕЙСТВИИ
}

\author{
Н.С. Дюрягина, А.П. Яловец \\ Южно-Уральский государственный университет, г. Челябинск, Российская Федерация \\ E-mail: nsdiuriagina@susu.ru
}

В рамках модели Роуза-Фаулера представлены результаты моделирования населенности локализованных состояний нанокомпозиционных материалов при длительном воздействии (больше 3 c) малой мощности $(0,002 \mathrm{BT} / к г)$ и импульсном воздействии $(100 \mathrm{нc})$ большой мощности (от 105 Вт/кг) радиационного облучения. Исследована роль локализованных состояний в проводящих свойствах нанокомпозиционных материалов на примере нанокомпозитов с дырочной (полиметилметакрилат (ПММА $)+\mathrm{CdS})$ и электронной $\left(\alpha-\mathrm{Al}_{2} \mathrm{O}_{3}+\mathrm{SrO}\right)$ проводимостями, а также чистых ПММА и $\alpha-\mathrm{Al}_{2} \mathrm{O}_{3}$. Показано, что мелкие ловушки влияют на скорость релаксации к равновесному значению радиационной электропроводности, а доля глубоких ловушек, глубина которых много больше $k T$, на чувствительность к поглощенной дозе ионизирующего облучения. Показано, что чистый ПММА и нанокомпозиты на его основе не пригодны для дозиметрии из-за большой доли мелких ловушек в спектре собственных локализованных состояний. Спектр оксида алюминия включает в себя только глубокие ловушки, поэтому данный материал является практически идеальным для накопления информации об ионизирующем излучении. Показано, что с точки зрения дозиметрии наиболее интересными являются нанокомпозиты на основе оксида алюминия, в которых концентрация примесных центров не превышает концентрацию собственных локализованных состояний, а размер наночастиц не превышает $\sim 2$ нм, когда доля мелких ловушек в примесном спектре мала.

Ключевые слова: нанокомпозиционные материалы; локализованные состояния; иентры захвата, ловушки, радиачионная проводимость; Роуз-Фаулер; дозиметрия; полиметилметакрилат (ПММA); $\mathrm{CdS} ; \alpha-\mathrm{Al}_{2} \mathrm{O}_{3} ;$ корунд; $\mathrm{SrO}$.

\section{Литература}

1. A route to diffusion embedding of $\mathrm{CdSe} / \mathrm{CdS}$ quantum dots in fluoropolymer microparticles / V.K. Popov, V.N. Bagratashvili, L.I. Krotova et al. // Green Chemistry. - 2011. - Vol. 13, no. 10. P. 2696-2700.

2. Designer polymer-quantum dot architectures / N. Tomczak, D. Janczewski, M. Han, G.J. Vancso // Progressin Polymer Science. - 2009. - Vol. 34. - P. 393-430.

3. Ванников, А.В. Радиационные эффекты в полимерах. Электрические свойства / А.В. Ванников, В.К. Матвеев, В.К. Сичкарь, А.П. Тютнев. - М.: Наука, 1982. - 273 с.

4. Кортов, В.С. Твердотельная дозиметрия / В.С. Кортов, И.И. Мильман, С.В. Никифоров // Известия Томского политехнического университета. - 2000. - Т. 303. - С. 35-45.

5 Мильман, И.И. Температурное тушение в люминесенции анионодефектных кристаллов

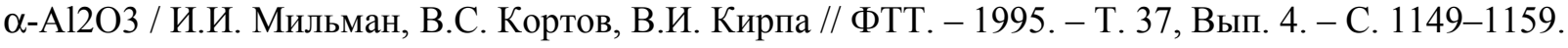

6. Никифоров, С.В. Моделирование сверхлинейности дозовых характеристик термолюминесценции анион-дефектного оксида алюминия / С.В. Никифоров, В.С. Кортов, М.Г. Казанцева // ФТТ. - 2014. - Т. 56, Вып. 3. - С. 536-541.

7. Никифоров, С.В. Моделирование сублинейной дозовой зависимости термолюминесценции с учетом конкурирующего взаимодействия центров захват / С.В. Никифоров, В.С. Кортов // ФТТ. - 2014. - Т. 56, Вып. 10. - С. 1999-2003. 
8. Шамилов, Р.P. Композиты полиметилметакрилата на основе квантовых точек CdSe и $\mathrm{CdSe} / \mathrm{CdS}$, синтезированных в водно-этанольной среде / Р.Р. Шамилов, Ю.Г. Галяметдинов // Вестник Казанского технологического университета. - 2013. - Т. 16, Вып. 15. - С. 322-324.

9. Тютнев, А.П. Радиационная электрофизика органических диэлектриков / А.П. Тютнев, А.В. Ванников, Г.С. Мингалеев. - М.: Энергоатомиздат, 1989. - 192 с.

10. Тютнев, А.П. Численный анализ модели Роуза-Фаулера-Вайсберга / А.П. Тютнев, Д.Н. Садовничий, С.Г. Боев // Радиационная химия. - 1995. - Т. 29, Вып. 2. - С. 115-119.

11. Experimental and Theoretical Studies of Radiation-Induced Conductivity in Spacecraft Polymers / A.P. Tyutnev, V.S. Saenko, E.D. Pozhidaev, R. Ikhsanov // IEEE transactions on plasma science. - 2015. - Vol. 43, Issue 9. - P. 2915-2924.

12. Dyuryagina, N.S. Using Rouse-Fowler model to describe radiation-induced electrical conductivity of nanocomposite materials. / N.S. Dyuryagina, A.P. Yalovets // J. Phys.: Conf. Ser. - 2017. Vol. 830, Issue 1. - P. 12130-12136.

13. Вайсберг, С.Э. Исследование радиационной электропроводности полимеров / С.Э. Вайсберг, В.П. Сичкарь, В.Л. Карпов // Высокомолекулярные соединения. - 1971. - Т. (А)13, Вып. 11. - С. 2502-2507.

Поступила в редакцию 2 ноября 20172. 